Society and Economy 36 (2014) 2, pp. 263-283

DOI: $10.1556 /$ SocEc.36.2014.2.7

\title{
FISCAL CYCLE EFFECTS IN THE PATTERN OF THE HUNGARIAN STATE EXPENDITURES ${ }^{1}$
}

\author{
ÁGNES HALÁSZ \\ PhD Student, University of Debrecen Doctoral School of Economic Science \\ Email:halaszagnes@mailbox.hu
}

In this paper we aim to investigate what role fiscal cycles played in the development of the Hungarian state budget balances since the change of regime in 1989 until the parliamentary elections held in 2010. The literature has found that political budget cycles (PBC) are more typical in less developed countries with a shorter period of experience with democratic institutions, like the post-socialist transition economies. Nevertheless, empirical studies point out that this phenomenon has been disappearing over time. By testing the six parliamentary elections in Hungary until 2010, we show that discretional governmental actions of pork barrel spending were apparent more or less in almost each election period, peaking in the last decade. The most typical form of the fiscal cycles in Hungary proved to be social transfers to households including old-age benefits, family support or price subsidies, but also public sector wages were subject to PBC. As a result, state budget balances were significantly shaped by the cyclical movements of fiscal laxity and restrictions, resulting in strong fluctuations in fiscal balances and an overall high budget deficits in the two decades under review.

Keywords: political budget cycles, state expenditures, new democracy, Hungary

JEL codes: D72, E62, H3

\section{INTRODUCTION}

The Hungarian public finance sector has developed rather unfavorably since the end of the Communist regime: amid rather strong volatility, general government balances approximated an average $6 \%$ budget deficit in terms of GDP over the period between 1990 and 2010. While in the early nineties it was failed stabilization,

401 The author thanks István Benczes for his support and valuable comments. 
from the new millennium it has been the welfare turnaround that threatened budget positions. Financial indiscipline and massive indebtedness was generally typical of all Hungarian governments irrespective of their political affiliation. Nevertheless, cyclical evolution of the budget balance apparently was peaking around years when parliamentary elections were held in Hungary. In the literature this phenomenon is well known as political budget cycle (PBC) when incumbent politicians change economic policy so that they favor special groups of voters for the sake of improving reelection prospects. The influential paper by Brender and Drazen (2003) found that budget cycles are more typical in the less developed, new democracies since voters in such countries do not have enough experience with political incentives and manipulation. Within new democracies, the authors confirmed an expenditure side cycle in the case of post-socialist transition countries. However, PBC gradually disappears over time. As electors learn how democratic institutions operate, politicians cannot manipulate them anymore and consequently, PBC will vanish. Drazen (2001) showed some estimated four election 6 cycles are necessary for this so-called learning-by-doing process. This theory, 17 however, does not seem to be strengthened by the Hungarian pattern: PBC did not 18 vanish in the case of Hungary. Moreover, it strengthened throughout the 2000s 19 and was the strongest in 2002 and 2006. To explore this apparent contradiction, 20 the next section will briefly review the literature on PBC, followed by an analysis

\section{THEORETICAL BACKGROUND}

\subsection{Traditional models of political business cycles}

Two basic models serve as a pillar for political business cycle (PBC) theories. One is the opportunistic (and free of ideology) model of Nordhaus (1975). The other is the so-called partisan model established by Hibbs (1977). These basically say in electoral periods incumbents who wish to maximize the possibility of remaining in office in the short term, heat the economy up by using active economic policy and cool it down afterwards by restrictions. As a result of the process, ex ante economic performance strengthens and income grows, unemployment shrinks, thus social contentment improves. After elections, incumbents tighten fiscal policy in order to cool the economy down.

In Nordhaus's model the economy is summarized by a non-stochastic, expectations-adjusted Phillips curve, describing the conventional negative inflation-output trade-off. In his model households are rational in their preferences and ignorant of the macro-economic trade-off, while they have adaptive price expecta- 
tions. Furthermore, households are myopic - that is they rely on present economic performance when making political decisions and also suffer from fiscal illusion stemming from the vote of confidence they give to the winning party after the elections. In a simplified version, the Nordhaus model predicts that public choice creates political business cycles with a lower than optimal rate of unemployment thus higher inflation levels prior to elections, and inversely, higher unemployment and lower price levels afterwards (Nordhaus 1975: 185). A key feature of this theory comprises the government's ability to affect real factors.

Nevertheless, several basic conditions of the Nordhaus model seem to be rather simplified or less realistic. First, households cannot be considered to possess a rational attitude since being myopic and having adaptive expectations endow them with features that enable policy makers to abuse electors systematically. As a result of the ex ante expansion, they reward politicians by voting for them and ignoring past experience (Alesina 1988: 15). A second criticism refers to that Keynesian ability of the government to affect real factors by monetary instruments. The neo-classical Lucas-critique and rational expectation theory decreased the ground for the economic impact of state measures. Finally, Nordhaus fully ignored the usual political motives of left- and right-wing parties and put his model into an environment free of ideology.

The Hibbs model of partisan policymakers is similar to that of Nordhaus, however, here the partisan differences are the key driving forces. Thus policymakers have different economic goals. That is, politicians' attitudes to inflation and unemployment are determined by their ideological status, as conservative parties generally prefer lower inflation, while left-wing parties prefer lower unemployment (Hibbs 1977). Again, the major defect of Hibbs' theory is the neglect of rational expectations. Alesina (1988) later filled this gap in his rational-partisan model. He places the model into a formal framework as well, and describes interactions between the two main parties by using game theory.

Empirical studies, however, show mixed results; statements of the traditional models could not clearly be proved. ${ }^{2}$ Tests have made it evident that aggregate economic conditions like per capita output or income growth do affect voting patterns significantly. Experiences of quite a few countries show no strong increase in aggregate economic activity prior to election, whilst an apparent post-electoral rise in inflation can be identified (Drazen 2001: 83-85).

35

36

37

38

39

40
2 See empirical tests on traditional models inter alia: McCallum (1978); Tufte (1978); Alt Chrystal (1981); Alesina - Sachs (1988); Lewis-Beck (1988); Alesina et al. (1989); Alesina Roubini (1992). 
3 The 'golden age' of the traditional PBC models does not last long due to the lack 4 of demonstrative empirical evidence and exaggerated simplifications of condi5 tions. Instead, these models provide a strong foundation for the subsequent evolution of PBC theories. Early variants of the second-generation models are also based on political manipulation, however; in this case the principle of deception is meant to be the information asymmetry of the otherwise rational voters, instead of their naive attitude to the political system. However, these rational PBC models established by Persson and Tabellini (1990) - endorse the Phillips curve and the governmental activity of manipulating monetary instruments effectively. The latter condition is highly inaccurate, at least in the developed countries operating with independent central banks. A real separation from the tradition, thus a clear breakthrough in the PBC theory was particularly hallmarked by the work of Rogoff and Sibert (1988) and Rogoff (1990), who reject the Phillips curve and instead, focus on fiscal policy when explaining PBC. In this sense, they applied a new phrase for the phenomenon, calling it "political budget cycles" for life. ${ }^{3}$ When specifying political budget cycles, we might use the definition by Benczes and Kutasi, who identify budget cycles as a regularly recurring periodical fluctuation in governmental fiscal policy induced by elections. Its impact is particularly perceivable in the magnitude of government deficit and/or state debt, as well as the structure of state revenues and expenditures (Benczes - Kutasi 2010: 224).

The early millennium brought a new wave of research by Persson and Tabellini (2003) along with Shi and Svensson (2002a; 2002b) leading up to moral hazard models founding the third generation of PBC. These models are also based on the competence of incumbents. According to the moral hazard approach neither electors nor politicians can directly measure the productivity/competence of incumbents, namely their ability to produce public goods without raising taxes (Shi Svensson 2003: 70). Incumbents are naturally aware of this phenomenon, therefore they generate higher budget deficit financed by excessive borrowing in order to present themselves more competent (Benczes - Ürögdi 2008: 269).

Opening a new chapter in the PBC research, the approach of Rogoff (1990) also gave impetus to new empirical investigations. ${ }^{4} \mathrm{We}$ observed that the PBC literature was becoming more and more sophisticated with time largely since the diverse and often contradictory empirical results stimulated researchers to find new

In the following PBC refers to political budget cycles instead of political business cycles. See empirical evidence on political budget cycles inter alia: Ames (1987); Schuknecht (2000); Block (2002); Brender - Drazen (2003); Andrikopoulos et al. (2004); Alt - Lassen (2006); Mink - de Haan (2006). 
explanations and contexts. The second and third generations showed us that the politicians' ability to manipulate depends on the depth of information asymmetry between incumbents and electors (Benczes - Kutasi 2010: 230). Research results overall and in general indicated the trend that Rogoff's model can be verified typically in less developed and developing economies, whilst the pattern of developed and industrialized countries showed no political fiscal cycles in connection with election periods. The reasons for this kind of divergence might from this point be searched for in institutional factors.

\subsection{PBC in old and new democracies (deficit bias and learning by doing)}

The institutional reasons for the information asymmetry were investigated inter alia by Brender and Drazen (2003), who conclude that the underlying factor of the different empirical results is the quality of democratic institutions. That is, the more mature and solid operation a democracy has, the smaller the probability of so-called pork barrel spending (see Drazen - Eslava 2006). Brender and Drazen (2003) re-examined empirical results on the existence of political budget cycles in a cross-section of countries. Using a large sample of 107 countries between 1960 and 2002, they found evidence of fiscal cycles in the budget balance, the strength of which though depends on several factors. Therefore they classified two types of democracies: the established "old" democracies and the "new" ones. During the first test, developed OECD economies were analyzed, where Greece, Portugal, Spain and Turkey received the label new. In the first round of testing, PBC was confirmed in developed countries both for revenues and expenditures and the overall budget balance. In the second round of the tests, after excluding the four new democracies, however, the PBC disappeared, meaning that the new democracies are responsible for the fiscal cycles in the developed economies (BrenderDrazen 2003: 13).

Afterwards, they considered the sample of both developed and developing countries as a whole, and here again evidence of PBC was found. When distinguishing new from established democracies, the PBC vanished. These results show that $\mathrm{PBC}$ is more characteristic of the less developed new democracies. Furthermore, Brender and Drazen conclude that within the group of new democracies it is the sample of former socialist economies that drives the coefficient on the expenditures. When these are excluded, the expenditure cycle disappears, though the fiscal balance cycle remains significant (Brender - Drazen 2003: 14).

An alternative hypothesis is that it is not the length of time a country has been a democracy but the level of democracy that matters for the existence of a political fiscal cycle. Namely, PBC might be a phenomenon of countries where democracy 
1 is relatively weaker as Shi and Svensson (2002b) assumed. However, here again 2 they found PBC in new democracies is significant, regardless of the level of de3 mocracy. The reason for this might be that the proportion of new democracies in 4 the group of weak democracies is higher (Brender - Drazen 2003: 16).

For these divergent results, Drazen's theory (2000) may serve as an explanation, by claiming that in new democracies, voters have less experience with the operation of democratic institutions, and thus they do not know the rent-seeking ambitions of policymakers and the forms of political manipulation. Fiscal cycles thus stem from this lack of knowledge and not from the non-rational behavior of voters. Consequently, voters in new democracies need some time to become familiar with and learn political incentives. Thus, after a while voters will punish incumbents for pork barrel spending. According to Drazen, this is the necessary and inevitable process of "learning-by-doing" in new democracies including the post-socialist Central and Eastern European economies. These new results seem to have dissolved the conflict between rational attitude and the empirical evidence so far (Benczes - Ürögdi 2008: 272).

Fiscal illusion and apparently non-rational voter behavior both derive from the lack of experience, resulting in information asymmetry. This phenomenon is more characteristic of the new democracies, though it is disappearing with time. As for the "time" required, Drazen found that four election cycles are necessary. That is, voters need approximately 16 years to complete the process of learningby-doing (Benczes - Kutasi 2010: 232).

One might summarize empirical results of Brender and Drazen from our point of view as follows: (1) there is significant PBC in fiscal balances in post-socialist transition, which is generated by (2) an expenditure's side cycle. (3) The cycle, however, gradually disappears as voters learn how democratic institutions operate. (4) For this learning-by-doing process four election cycles are needed, that is, after some 16 years PBC is less likely to be found in these countries.

In the next section we are test this hypothesis in the case of Hungary, a post-socialist new democracy since 1990. Twenty-three years and five election cycles have passed since the regime change. The basic assumption is that around the 1994 and 1998 elections expenditure side fiscal cycle was perceivable, but then it gradually faded and disappeared by the parliamentary election held in 2006 . We do not take the first, 1990 election into consideration. Since in post-socialist countries, economic transition occurs simultaneously with political transition, without either one causing the other, distinguishing PBC from an inherent rise of deficit is rather limited (Brender - Drazen 2003: 13). 


\subsection{The transition period and the stabilization: 1990-1998}

\subsubsection{0-1994}

At the onset of the transition Hungary was a leading country in reforms, nevertheless, transformational recession lasted 4 years - unlike in the Czech Republic or Poland - and the upswing afterwards remained more moderate (EBRD 1997). Hungarian growth prospects were largely worsened by a delay in macroeconomic stabilization. Failing to stabilize consequently caused deterioration in budget balances. At the onset of transition efficient fiscal policy in theory requires quick reaction from the government's side to shocks caused by the crisis and proper reduction in state expenditures, as well as tax increase. This, however, was not experienced in Hungary. Cabinets kept on stalling stabilization programs until the mid-1990, thus inducing rising budget deficits (IMF 1997a).

Declining output and rising unemployment increased social pressure, which in turn weakened political will to adjust. Parallel with transformational recession a severe decline in the number of workplaces and employment rate was seen in the Hungarian private sector, a consequence of which masses of people were forced out of the labor market, and then chose early retirement and disability schemes in order to escape from long-term unemployment. The employment rate for Hungarians between 55 and 59 years old stood at only 26.8 per cent in 1995 (OECD 1997: 79). Thus throughout the 1990s the number of disability pensioners rose from 204 to 425 thousand people, some 10.4 per cent of the labor force (IMF 2000: 14). Along with an already low official retirement age level, these processes resulted in middle-aged classes with working ability becoming totally state-dependent. Thus the total number of benefit recipients of various income support schemes equaled around 12 per cent of the working-age population in 1990 increased to some 22 per cent in 1993-1994 (OECD 1997: 103).

The conservative governments between 1990 and 1994 did not deny consumption orientation and in times of significant transitional recession incumbents were unwilling to curb wide-scale provision of welfare spending (Benczes 2011). After 1989, the first free government of Hungary was characterized rather by an overall drifting in terms of fiscal policy until the Bokros-package (Kornai 1996). Primary expenditures increased from 48 per cent of GDP in 1991 to 54 per cent in 1993 and also showed a nominal cumulated growth of 58 per cent between 1991 and 1993. As a consequence, primary deficit reached 3.1 per cent of GDP by 1993, whilst the overall government budget balance equalled -8 per cent (IMF 1997b). The deficit was largely strengthened by a decline on the revenue side (caused by the large vol- 
ume of tax arrears of enterprises) to which, however, expenditures did not adjust. By 1994 transfers to households amounted to 20 per cent of GDP, half of which accounted for pensions (Haggard et al. 2001: 80).

Although state transfers played an outstanding role in alleviating increased wage inequalities driven by transformation, several factors anticipate that these benefits - e.g. the indexation method or the replacement rate (OECD 2005b: 50) were rather generous. Gál (2008) found discretional state measures around elections played a significant role in the evolution of pension expenses. Furthermore, the share of compensation of public employees also reached its first peak in 1994 since 1990, amounting to about 22 per cent of total outlays (Benczes 2008: 175). To the run-up to the next election to be held in 1994, not only the adjustment lagged, but also the restructuring process slowed down (Kornai 1996).

\subsubsection{4-1998}

Voters replaced the conservative cabinet in 1994 with a socialist-liberal government which faced a massive economic legacy: on the one hand, internal and external imbalances, as well as delayed macroeconomic stabilization, and on the other hand a failed agreement with the IMF on a standby credit facility which led to a loss of confidence in global markets. A death blow was delivered by the Mexican crisis, which might also have meant to be an exemplary lesson finally resulting in a governmental commitment to implement a radical adjustment (Kornai 1996: $588)$.

All these premises called for the stabilizing package hallmarked by the finance minister of the time, Lajos Bokros, which was introduced in March 1995. The adjustment was asymmetric in the sense it aimed to solve imbalances by decreasing internal consumption without hurting investments and exports (Kornai 1996: 598). Accordingly, a severe drop in industrial production and an economic recession could be evaded, and an improvement in both fiscal and current account balance positions was achieved. On the expenditure side, the stabilization package resulted in the largest savings in compensation of public employees and social benefits other than in kind.

The public wage bill declined from 13.8 per cent of GDP in 1994 to 10.8 per cent by 1996 (European Commission 2012: 153). This can be traced back to the unilateral restriction of nominal wage increase in public institutions.

As for social expenditures, the earlier universal social eligibilities were significantly tightened in 1995 and mainly made a condition of means tests. Although a large part of the social measures were later repealed by the Constitutional Court, the share of family benefits in total social security expenditures declined from 13 
per cent in 1992 to 8.5 per cent in 1996 (OECD 1997: 93). Furthermore, the package sent an important message to the population, especially in terms of social security outlays. Mr. Bokros emphasized on several occasions that the basic aim was to change individuals' perception of the state and demolish taboos, with respect to free public provisions (Benczes 2008: 159).

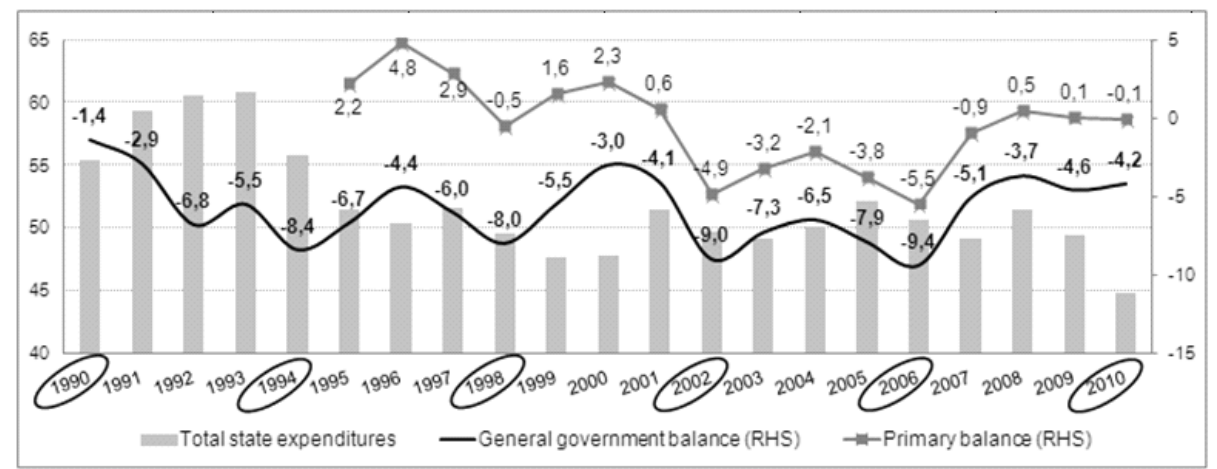

Figure 1. Development of the general government balance, primary balance and state expenditures in Hungary, 1990-2010 (in per cent of GDP)

Note: years of parliamentary elections are circled.

Source: EBRD 1997; European Commission 2012.

Thanks to the adjustment, the general government position improved significantly (Figure 1). Despite the stabilization and a strengthening economic performance from 1997, one experienced growing imbalances again and fiscal laxity was obvious in the running up to the next elections with deficits peaking in 1998.

The 1998 budget is very much an election-year budget. Subsidies for investment and agriculture were budgeted to rise substantially, while pensions and public-sector wages were set to grow by $22 \%$ and $13-16 \%$, respectively, leading to opposition accusations of vote buying. In January 1998 the government decided to give $\mathrm{Ft} 1.5$ bn from budget reserves to meet the demands of the healthcare union for a promised $16 \%$ wage increase for 1998, social benefits and comprehensive regulation of overtime payments (EIU 1998a: 19-20).

Indeed, actual figures show a realization of these proposals. Despite a decline in unemployment, social expenditures rose in terms of GDP (OECD 2000: 64). Pension costs escalated by more than 14 per cent at real terms, and despite a disinflation trend, drug subsidies also increased strongly (OECD 2000: 69). As a result of this excess, pharmaceutical subsidies that generally count for 25 per cent of the health fund's total expenditures increased to 30 per cent. 


\subsubsection{Summary}

The early nineties witnessed an increasing focus on welfare spending instead of stabilization (see Muraközy 2005), leading to a - using Kornai's phrase - premature welfare state. This process until 1995 makes it difficult to identify clear PBC effects from the general trend. Still, in 1994 some fiscal cycle factors were identified mainly in pensions and drug subsidies. By the elections in 1998, however, PBC had strengthened in these items due to governmental efforts to win the support of elderly generations. This seems to be rational from the incumbents' viewpoint when aiming to maximize votes, since - according to the data of the Hungarian Central Statistics Office (n.d.) - more than one-third of those eligible to vote receive pension benefits of various forms.

\subsection{The welfare turnaround and the period of "packages": 1998-2010}

\subsection{1. $1998-2002$}

PBC-elements in the budget of 1998 and also some last-minute attempts of vote-buying actions ${ }^{5}$ as of early 1998 failed to have the desired effect (EIU 1998b: 21). Voters seem to have punished the government for the effects of the Bokros-package, the left-wing coalition was thus replaced by a new conservative government with the leadership of the Fidesz party. One might divide the 4-year cycle of the Orbán-cabinet into two periods: ${ }^{6}$

1. Although the new government also played a role in worsening 1998-budget outcomes, ${ }^{7}$ as well as endorsing several election program elements in the 1999-budget - e.g. pension increase by 11 per cent, an increase in governmental agricultural subsidies by 30 per cent, replacing the need-tested family support system enacted by the previous government with an across-the-board set of benefits (EIU 1999a: 22) - what appeared to be fiscal discipline characterized the conservative cabinet until 2000 (Benczes 2008: 163). Namely, de-

5 35

E.g.: proposal for a $2.5 \%$ increase to pensioners retroactive to January 1998; providing HUF 14 bn in support for 600,000 families with an accumulated HUF 15 bn debt for utility and home-loan payments; increasing subsidies for agricultural building and cropland investment in April from HUF 11.5 bn to HUF 17 bn.

6 Between 1998 and 2000 economic growth accelerated and exceeded 5 per cent by 2000 . However, from 2001 GDP growth slowed down due to the deceleration of external demand impacting investments in the private sector negatively (OECD 2002: 23).

7 Several one-offs caused budget pressures (EIU 1999a). 
spite all these fiscal pressures, increasing tax revenues driven by strengthening economic growth helped to more than counterbalance the rise in expenses (Table 1). On the whole, the general government position developed more favorably in 1999 than in 1998, but still the deficit remained high, in which debt service also played a notable role (Figure 1).

2. From 2001, however - approaching the 2002 elections, the government's poll rating still being low - a U-turn was seen. Despite spending commitments to meet NATO obligations and EU accession demands, the government pursued fiscal laxity in different forms:

- Social security benefits paid by the government increased faster than GDP, because the government increased pensions well above the amount implied by the statutory formula (OECD 2002: 61). Pensioners further received a one-off supplementary payment of HUF13 bn (NBH 2003: 21).

- The government also proposed a large increase in family support (EIU 2000b: 24). As a result, Hungarian family benefits in terms of GDP became the third largest among OECD countries in 2003 (OECD 2004: 76).

- Various forms of grants (e.g. interest subsidies, tax breaks, etc.) of the housing program launched by Fidesz in 2000 were also increased (Farkas et al. 2004).

- Further funds are also expected to be found for the agriculture sector, on top of the extra HUF1.5bn already transferred to the agriculture ministry (EIU 2000b: 23-24).

- The massive increase in public infrastructure spending is recorded partly in the gross fixed investment row, partly in subsidies and goes partly off-budget.

- But above all, the largest election cycle element was in particular the large-scale wage raise for public-sector workers aiming to compensate for higher than expected inflation and to prevent embarrassing labor protests in the run-up to the election.

The 2002 election period served as a new experience in forms of pork-barrel spending. To understand why the strong expansion of public-sector wages and the massive minimum-wage hike can be evaluated as election cycle measures, one ought to consider the following factors and circumstances:

1) An average of 800 thousand individuals are employed in the Hungarian public sector, that is approximately 16 per cent of those eligible to vote, and thus embody a politically sensitive group.

2) Throughout the nineties the wage gap between the private and public sector increased continuously (EIU 1999c: 19). Thus by the millennium wage pres- 
sures peaked in the public sector leading to troubled relations between the government and the trade unions as well as large-scale demonstrations. ${ }^{8}$

3) But not only public servants were discontent, as poll results showed that ruling parties were losing support, since a wide range of electors voting for the government in 1998 did not benefit from the export-driven economic growth. Social and regional income inequalities remained high, and many pensioners, farmers and low-income blue-collar workers drew back from the government (EIU 2000a: 16).

Increasing disaffection strengthened political pressure on the conservative government and also its reluctance to meet restrictive actions in the second half of its cycle. Originally in the two-year budget of 2000-2001 the cabinet planned to cap wage growth at 2.8 per cent and cut staff numbers by 7-8 per cent in the public sector (EIU 1999c: 19). In the run-up to the 2002 elections, however, the opportunity to recognize the pork-barrel spending from this social pressure might also have played an important role in the growing laxity of the wage policy affecting particularly the above-mentioned groups:

- The government instituted a new formula for determining public-sector wages, which adds one half of real GDP growth to expected inflation, thanks to which public sector wages increased significantly (OECD 2000: 32). Furthermore, a large-scale wage hike complemented this measure. In the first round as of July 2001 civil servants and public order officers received a rise from 35 to 55 per cent for both groups, afterwards, the latter group was given a further increase of 15 per cent in early 2002 (OECD 2004: 50).

- The statutory minimum wage was practically doubled in 2001 and 2002. Consequently, the minimum wage rose by 65 per cent in real terms in two years. The ratio of the minimum wage to average gross salary jumped to an extremely high 43 per cent in 2002 - which was in strong contrast with the previous level of 30 per cent or less that was characteristic after 1995. Moreover, the minimum wage became tax-free in 2002; therefore the revenue side of the budget also suffered a substantial loss (Benczes 2008: 176).

As a result of all these spending measures, the annual increase in compensation of employees, social transfers and also gross fixed capital formation accelerated

8 E.g. an estimated 18,000 public employees demonstrated in front of the Parliament in late March, demanding that the government lift its freeze on public-sector wages and civil-service salaries, increase public-sector wages by $16 \%$, and rescind a decision to cut the number of public-sector employees by 3\% (EIU 1999b: 17). 
1 by 2002 (Table 1). General government deficit deteriorated from 3 per cent of

2 GDP in 2000 to 4.1 per cent in 2001 and to 9 per cent in 2002. Meanwhile, primary

3 balance from a surplus of 2.3 per cent of GDP in 2000 fell to a deficit of 4.9 per

4 cent by 2002 (Figure 1). Albeit some non-PBC one-off expenditure items ${ }^{9}$ also 5 played a significant role in the deterioration, an adjustment to these does not 6 change the overall unfavorable picture of public finances.

Table 1

Consolidated general government revenues and expenditures in Hungary, 1999-2002 (ESA-95)

$\begin{array}{lllll}1999 & 2000 & 2001 & 2002 & \begin{array}{c}2002 \\ \text { in per cent } \\ \text { of GDP }\end{array}\end{array}$

\begin{tabular}{lrrrrr}
\hline TOTAL REVENUES & 12.2 & 16.9 & 10.3 & 11.9 & 43.4 \\
TOTAL EXPENDITURES & 7.1 & 10.8 & 14.4 & 22.7 & 52.6 \\
Current expenditures & $\mathbf{1 3 . 1}$ & $\mathbf{8 . 7}$ & $\mathbf{1 3 . 5}$ & $\mathbf{1 6 . 4}$ & $\mathbf{4 3 . 2}$ \\
Government consumption expenditure & \multicolumn{1}{|c}{12} & 13.6 & 15.7 & 17.8 & 18.6 \\
$\quad 11.7$ & 12.8 & 19.9 & 22.7 & 11.8 \\
$\quad$ of which: final wage expenditure & 14.1 & 8.1 & 17.2 & 18.4 & 15.9 \\
Social security benefits paid & -13.2 & 232 & -29.6 & 26.6 & 1.2 \\
Other current transfers paid & 58.2 & -12.5 & 43.2 & 29.7 & 3.3 \\
Subsidies & 3.8 & -12.2 & -1.9 & -5.2 & 4.1 \\
Property income paid & $\mathbf{2 6 . 8}$ & $\mathbf{2 9 . 4}$ & $\mathbf{1 7 . 5}$ & $\mathbf{5 8 . 3}$ & $\mathbf{8 . 3}$ \\
Capital expenditures & & & & & \\
\hline
\end{tabular}

Source: OECD (2004: 51).

\subsubsection{2-2006}

Vote-buying actions proved to be successful as Fidesz made steady gains until December 2001, when the party took the lead over the HSP (EIU 2002a: 15). Nevertheless, the ruling parties finally lost the elections of 2002 and thus were replaced by a socialist-liberal government. In accordance with the election promises, the new prime minister Péter Medgyessy introduced the comprehensive package of 'The first 100 days' program, as a result of which the government overall spent some 320 bn Forints (some 2 per cent of GDP) on welfare measures and wage hikes. It is difficult to assess clearly whether this spending was primarily caused by the tight result of the election or the approaching election in the local governments in the fall of 2002. Perhaps the intention was to keep election promises or to make voters forget the Bokros-package. Nevertheless the fact is, despite

9 E.g. capital injection at the Hungarian Development Bank and consolidation of state railway (MAV) loans amounting to HUF 180 bn (EIU 2002c: 21). 
1 typical PBC in theory requiring restrictions after elections, the socialist-liberal 2 government announced a welfare turnaround in social policy and continued 3 spending.

4 First, within the framework of the "First 100 days program" the government 5 continued wage hikes in the public sector with further significant allocations be6 ing implemented in the case of public and civil servants as well as employees in 7 the judiciary system (OECD 2004: 50). As a result of all these wage increase mea8 sures, compensation of employees in terms of GDP grew from 10.8 per cent in 92000 to 13.3 per cent in 2003 (European Commission 2012: 153). Consequently, 10 the Hungarian indicator over-performed both its regional peers and that of devel11 oped western countries (Benczes 2008: 172).

Second, welfare expenditures were also increased. In line with the announced welfare turnaround the cabinet raised family allowances, in addition, in August 2002, families received the double of their monthly amount of family support payment to compensate for higher school expenses (EIU 2002b: 22). Furthermore, pensioners received a HUF 19,000 lump sum payment and a $13^{\text {th }}$-month pension was promised. As of January 2003, a pension increase of 8.4 per cent was implemented and a further 2.2 per cent supplement was envisaged in November in line with expected inflation and net wage developments (Convergence Programme 2004: 20).

As a result of strengthening state paternalism and rising welfare spending in the first half of the 2000s, social transfers other than transfers in kind increased from 12.8 per cent of GDP in 2000 to 14 per cent by 2004 (European Commission 2012: 157).

The typical PBC cycle of restriction after elections was first perceivable in 2004 when the so-called Draskovics-package - named after the finance minister at the time - aimed to implement a fiscal austerity of HUF 120 bn (around 0.6 per cent of GDP), mainly by savings in non-wage expenditures at ministries and state investments (OECD 2004). Overall, solely a slight improvement can be seen in actual budget figures (OECD 2005a).

From 2005 on, in the run-up to the elections of 2006, PBC sharpened again. After gaining EU-membership as of May 2004, the ruling HSP performed rather poorly in the European election held in June, which led to internal conflicts within the coalition and finally ended with the abandonment of the prime minister, who was otherwise not even a member of either ruling party (EIU 2004a: 14). The new Gyurcsány-cabinet was highly expected to improve the popularity of the HSP until 2006. In this sense the new cabinet launched 'The 100-step program, ${ }^{10}$ in April 2005, focusing especially on low-income groups:

10 The choice of name served the purpose of reminding voters on the achievements of the 'First 100 -days program'. 
- The program restructured significantly and also simplified the system of family benefits. On the one hand, benefits became universal, though with differentiations favoring poorer households. The amount of family allowances doubled and specified groups received increased transfers (Ferge 2006).

- In the pension system the $13^{\text {th }}$-month pensions were to be completed in 2006 and the program of medium-term adjustment of pensions was to commence as well. Widow's pensions were to be increased from 50 to 55 per cent for those having no pension in their own right (Convergence Programme 2005).

- Along with pensions, pharmaceutical subsidies also played a significant role in the budget deficit of 2005 (EIU 2005a: 18).

- PBC effects were also perceived in housing grants. On the one hand, the government aimed to help the needy in acquiring dwellings and also managing existing debts, yet on the other hand, interest rate subsidies increased (EIU 2004b: 23). As a result, housing grants reached outstanding annual growth and exceeded the budgeted level significantly as well (Central Statistics Office n.d.b).

\subsection{3. $2006-2010$}

As a result of the above-mentioned pork-barrel spending, at the end of 2005 polls showed that the HSP enjoyed a remarkable turnaround in support in the last quarter of 2005 (EIU 2005a: 7) and indeed it managed to double by winning the elections held in spring 2006 - the first time a party achieved this since 1990 . We are not analyzing the reasons for the success in deep detail, although it seems welfare spending in 2002-2003 convinced voters that the party keeps its promises, which was further enhanced by 'The 100-step program' of the Gyurcsány-cabinet. The worst was yet to come for voters: the second Gyurcsány-cabinet immediately reacted to the tragic stance of public finances, by increasing the budget deficit target from 6.1 per cent to 10.1 per cent and announcing a severe austerity program called the 'New Equilibrium Program'. The program, which also included structural reforms, aimed to realize both revenue increase and expenditure cuts (Convergence Programme 2006). The latter included inter alia: reduced pricing subsidies for household energy and transport; a two-year spending freeze at ministries, with lay-offs of approximately 15,000 state employees; savings in pharmaceutical price subsidies (EIU 2006: 17).

Although austerity already affected public finance in 2006, the final general government balance figures amounting to 9.4 per cent of GDP reached the highest level since 1990. In addition, in this process several technical factors also played a 
role (see OECD 2007), and PBC sharply stood out, as discussed. Pension expenditures and retail price subsidies strongly exceeded budgeted levels (OECD 2007). Also, the share of pharmaceutical subsidies in total health expenses peaked in 2006 increasing to around 23 per cent in 2006 from 19 per cent in 2003.

Restrictive fiscal policy continued in 2007, thus positively affecting budget processes, with general government deficit improving to 5.1 per cent of GDP, and primary balance almost reaching zero. The strongest positive contributors in the deficit reduction were higher tax revenues as well as savings in compensation of employees, government consumption and investments. An important feature of the Gyurcsány-package was that expenditure cuts did not touch politically sensitive areas like social transfers other than social transfers in kind. Moreover, pensions, family transfers and social benefits rose nominally and with each year of the adjustment these contributed to a higher deficit (Convergence Programme 2007: 18). Following the consolidation, the government intended to implement some fiscal laxity in the second half of the cycle that was, however, defeated by the outbreak of the global financial and economic crisis in October 2008. Since Hungary is deeply integrated in the international financial and economic processes, the spillover effects of the turbulence immediately became apparent, strengthened by a high debt ratio and thus a loss of confidence resulting in dramatic deterioration in the fiscal positions of Hungary. To manage the drying-up of financial resources the government agreed with international institutions on a rescue package of EUR $20 \mathrm{bn}$. Conditions of the credit facility as well as economic downturn ${ }^{11}$ envisaged further fiscal tightening. Accordingly, October 2008 and early 2009 saw further adjustment measures already affecting social welfare systems (EIU 2008: 12).

In March 2009, however, the prime minister unexpectedly announced his resignation. His successor, Gordon Bajnai was a technocrat, who aimed to stabilize public finances, and thus continued austerity of around HUF 1,300 bn (some 5 per cent of GDP) in 2009-2010 by curbing social spending significantly(EIU 2009a: 13). ${ }^{12}$ As a result of these processes, the general government balance prior to the 2010 elections remained disciplined around a deficit of 4 per cent in 2008-2010 and the primary balance gained a slight surplus in 2008-2009 despite a massive recession in 2009 (Figure 1).

As a result of these developments, there was absolutely no chance for the government to run budget cycles in the run-up to the 2010 parliamentary elections. First, the crisis clearly eroded every intention for this and unlike other European countries the Hungarian incumbents did not even have the opportunity to counter-

112009 saw a real GDP drop of 6.8 per cent.

12 Cancelling the $13^{\text {th }}$ month pension and wage in the public sector, increasing the official retirement age, delaying the pension correction scheme, freezing public sector wages, significantly cutting social expenditures, housing grants and price subsidies.

Society and Economy 36 (2014) 
balance the negative crisis effects by running expansive fiscal policy due to the above-mentioned factors. Second, Prime Minister Bajnai was a reformist politician, who was not member of the HSP, and announced several times his intention to resign if he did not receive the party's support for the budgetary measures. Third, the fiscal rules implemented in 2008 were also against a PBC. Consequently, support for HSP tumbled into the deep and saw historical lows (EIU 2009b: 10). According to polls, voters definitely punished the party for the austerity in the 2010 elections and replaced it with the Fidesz party, giving it a twothirds majority in the Parliament.

\subsubsection{Summary}

Fiscal cycles have strengthened from the millennium: in the election period of 2002 extensive pork barrel spending was seen focusing on public sector workers, pensioners as well as families etc. That was further enhanced by an atypical inverse PBC of the early Medgyessy-cabinet. In the run-up to the elections of 2006 the socialist-liberal government targeted low-income classes, families with children and again pensioners. $\mathrm{PBC}$ is further strengthened by the immediate austerity announced after elections. Prior to the last election, 2010 no PBC was seen, however, underlying reasons for this are various.

\section{CONCLUSION}

This paper is aimed at investigating whether the phenomenon of political budget cycles (PBC) played a role in the unfavorable evolution of fiscal balances in Hungary between 1990 and 2010. According to much cited studies of Brender and Drazen (2003), cyclical fluctuations in state expenditures around parliamentary elections are perceivable in the less developed and less experienced new democracies, such as the post-socialist transition economies in Central and Eastern Europe. However, empirical studies have found that PBC is also disappearing from new democracies after about four election periods. In this sense the pattern of Hungary was tested for the period of 1990-2010 including five election cycles. By analyzing state expenditures, we have shown that the Hungarian pattern only partially confirms the implications of the theory. Our main results are the following:

1. On the one hand, as anticipated, significant political budget cycles were found in both the overall budget balance and the state expenditures in Hungary. Prior 
to elections incumbents tended to increase state expenditures and restrict it afterwards.

2. However, unlike what Brender and Drazen found in 2003, PBC did not vanish over time in the Hungarian pattern. Moreover, fiscal cycles continuously strengthened in the 2000s and were the strongest in the parliamentary election years of 2002 and 2006.

3. The most typical form of the fiscal cycles in Hungary proved to be social transfers to households including old-age benefits, family support or price subsidies, and public sector wages subject to PBC.

4. Although no PBC was found in the last election cycle of 2010, we also discussed that this pattern is not really testable due to both economic (crisis effects from 2008) and political (turbulence and a technocratic government in 2009-2010) reasons.

5. On the whole, one might claim that political budget cycles are more than alive in the new democracy of Hungary - even four election cycles after the change of regime - thus playing an important role in the generally high and cyclical evolution of budget deficit.

By testing Hungary on political budget cycles and showing that in the generally unfavorable position of public finances, fiscal cycles played a significant role, and new research questions arise - namely, whether the Hungarian pattern is unique and other new democracies in the region follow the model of Brender and Drazen, or not. In the case of diverging empirical results what are the underlying reasons? We are presuming that institutional factors do have an effect on political manipulation. Answering these questions, however, requires further detailed investigation due to the limited framework of the current paper.

\section{REFERENCES}

Alesina, A. (1988): Macroeconomics and Politics. In: Fischer, S. (eds): NBER Macroeconomics Annual, Volume 3. MIT Press.

Alesina, A. - Roubini, N. (1992): Political Cycles in OECD Economies. The Review of Economic Studies 59(4): 663-688.

Alesina, A. - Sachs, J. (1988): Political Parties and the Business Cycle in the United States, 1948-1984. Journal of Money, Credit and Banking 20(1): 63-82.

Alesina, A. - Mirrlees, J. - Neumann, M. (1989): Politics and Business Cycles in Industrial Democracies. Economic Policy 4(8): 55-98.

Alt, J. - Chrystal, K.A. (1981): Electoral Cycles, Budget Controls and Public Expenditure. Journal of Public Policy 1(1): 37-59.

39 Alt, J. - Lassen, D. (2006): Transparency, Political Polarization, and Political Budget Cycles in OECD Countries. American Journal of Political Science 50(3): 530-550. 
Ames, B. (1987): Political Survival. Berkeley: University of California Press.

Andrikopoulos, A. - Loizides, I. - Prodromidis, K. (2004): Fiscal Policy and Political Business Cycles in the EU. European Journal of Political Economy 20(1): 125-152.

Benczes, I. (2008): Trimming the Sails. Budapest - New York: CEU Press.

Benczes, I. (2011): Market Reform and Fiscal Laxity in Communist and Post-communist Hungary: A Path-dependent Approach. International Journal of Emerging Markets 6(2): 118-131.

Benczes, I. - Kutasi, G. (2010): Költségvetési pénzügyek [Fiscal finance]. Budapest: Akadémia Kiadó.

Benczes, I. - Ürögdi, A. (2008): A politikai költségvetési ciklusok új elmélete és empíriája [The new theory and empirics of political budgetary cycles]. Pénzügyi Szemle 53(2): 265-279.

Block, S. A. (2002): Political Business Cycles, Democratization, and Economic Reform: The Case of Africa. Journal of Development Economics 67(1): 205-228.

Brender, A. - Drazen, A. (2003): Where Does the Political Budget Cycle Really Come from? CEPR Discussion Papers No. 4049.

Central Statistics Office (n.d.a): Social security, social welfare (1960-), http://www.ksh.hu/ docs/eng/xstadat/xstadat_long/h_fsp001.html, accessed 14 March 2014.

Central Statistics Office (n.d.b): Lakáscélú hitelek (2001-) [Home-buying loans (2001-), http://www.ksh.hu/docs/hun/xstadat/xstadat_eves/i_zrh001.html, accessed 14 March 2014.

Convergence Programme (2004): Convergence Programme of Hungary 2004. Budapest: Government of the Republic of Hungary.

Convergence Programme (2005): Updated Convergence Programme of Hungary 2005-2008. Budapest: Government of the Republic of Hungary.

Convergence Programme (2006): Convergence Programme of Hungary 2006-2010. Budapest: Government of the Republic of Hungary.

Convergence Programme (2007): Updated Convergence Programme of Hungary 2007-2011. Budapest: Government of the Republic of Hungary.

Drazen, A. (2001): The political Business Cycles after 25 years. In: Bernanke, B. - Rogoff, K. (eds): NBER Macroeconomics Annual 2000, Volume 15. Boston: MIT Press.

Drazen, A. (2000): Political Economy in Macroeconomics. Princeton, NJ: Princeton University Press.

Drazen, A. - Eslava, M. (2006): Pork Barrel Cycles. NBER Working Paper No. 12190.

EBRD (1997): Transition Report. London: EBRD.

Economist Intelligence Unit (1998a): Country Report Hungary, March. London: EIU.

Economist Intelligence Unit (1998b): Country Report Hungary, June. London: EIU.

Economist Intelligence Unit (1999a): Country Report Hungary, March. London: EIU.

Economist Intelligence Unit (1999b): Country Report Hungary, May. London: EIU.

30

Economist Intelligence Unit (1999c): Country Report Hungary, September. London: EIU.

31

Economist Intelligence Unit (2000a): Country Report Hungary, August. London: EIU.

32 Economist Intelligence Unit (2000b): Country Report Hungary, November. London: EIU.

33 Economist Intelligence Unit (2002a): Country Report Hungary, February. London: EIU.

34 Economist Intelligence Unit (2002b): Country Report Hungary, May. London: EIU.

35 Economist Intelligence Unit (2002c): Country Report Hungary, November. London: EIU.

35 Economist Intelligence Unit (2004a): Country Report Hungary, August. London: EIU.

36 Economist Intelligence Unit (2004b): Country Report Hungary, November. London: EIU.

37 Economist Intelligence Unit (2005a): Country Report Hungary, August. London: EIU.

38 Economist Intelligence Unit (2006): Country Report Hungary, August. London: EIU.

39 Economist Intelligence Unit (2008): Country Report Hungary, December. London: EIU.

39 Economist Intelligence Unit (2009a): Country Report Hungary, April. London: EIU.

40 Economist Intelligence Unit (2009b): Country Report Hungary, July. London: EIU. 
European Commission (2012): European Economy, Statistical Annex, Spring. Brussels: European Commission.

Farkas, J. - Hegedűs, J. - Székely, G. (2004): Lakáshelyzet, lakástámogatások, 1999-2003 [Support for home buying]. In: Kolosi, T. - Tóth, I. Gy. - Vukovich, Gy. (eds): Társadalmi Riport 2004 [Social Report 2004]. Budapest: TÁRKI.

Ferge, Z. (2006): Kiket és mit szolgál a 100 lépés program? - Ellentmondásos előrelépések [Who and what does the 100 steps program serve? - Contradictory progress]. In: Tausz, K. (ed.): $A$ társadalmi kohézió erősitése [Strengthening social cohesion]. Budapest: Új Mandátum.

Gál, R. I. (2008): A nyugdijrendszer politikai kitettsége [The political vulnerability of the pension system]. In: Kolosi, T. - Tóth, I. Gy. (eds): Társadalmi Riport 2008 [Social Report 2008]. Budapest: TÁRKI.

Haggard, S. - Kaufman, R. R. - Shugart, M. S. (2001): Politics, Institutions, and Macroeconomic Adjustment: Hungarian Fiscal Policy Making in Comparative Perspective. In: Kornai, J. - Haggard, S. - Kaufman, R. R. (eds): Reforming the State: Fiscal and Welfare Reform in Post-socialist Countries. Cambridge: Cambridge University Press.

Hibbs, D. A. (1977): Political Parties and Macroeconomic Policy. The American Political Science Review 71(4): 1467-1487.

IMF (1997a): Hungary: Selected Issues. Country Report No. 97/103. Washington: IMF.

IMF (1997b): Hungary: Statistical Appendix. Country Report No. 97/104. Washington: IMF.

IMF (2000): Hungary: Selected Issues and Statistical Appendix. Country Report No. 00/59. Washington: IMF.

Kornai, J. (1996): Kiigazítás recesszió nélkül [Correction without recession]. Közgazdasági Szemle 43(7-8): 585-613.

Lewis-Beck, M. S. (1988): Economics and Elections: The Major Western Democracies. Ann Arbor: University of Michigan Press.

McCallum, B. T. (1978): The Political Business Cycle: An Empirical Test. Southern Economic Journal 44(3): 504-515.

Mink, M. - de Haan, J. (2006): Are there Political Budget Cycles in the Euro Area? European Union Politics 7(2): 191-211.

Muraközy, L. (2008): Magyarország felemelkedése és hanyatlása [The rise and fall of Hungary]. Közgazdasági Szemle 55(February): 149-168.

National Bank of Hungary (2003): Quarterly Report on Inflation. February, Budapest: MNB.

Nordhaus, W. D. (1975): The Political Business Cycle. The Review of Economic Studies 42(2): $169-190$.

OECD (1997): OECD Economic Surveys, Hungary. Paris: OECD.

OECD (2000): OECD Economic Surveys, Hungary. Paris: OECD.

OECD (2002): OECD Economic Surveys, Hungary. Paris: OECD.

OECD (2004): OECD Economic Surveys, Hungary. Paris: OECD.

32 OECD (2005a): OECD Economic Surveys, Hungary. Paris: OECD.

33 OECD (2005b): Pensions at a Glance. Paris: OECD.

34 OECD (2007): OECD Economic Surveys, Hungary. Paris: OECD.

35 Persson, T. - Tabellini, G. (1990): Macroeconomic Policy, Credibility and Politics. London: Harwood Economic Publisher.

36 Persson, T. - Tabellini, G. (2003): Do Electoral Cycles Differ Across Political Systems? Innocenzo Gasparini Institute for Economic Research Working Paper No. 232.

37 Rogoff, K. (1990): Equilibrium Political Budget Cycles. The American Economic Review 80(1): 38 Rogoff, $\mathrm{K}$.

39 Rogoff, K. - Sibert, A (1988): Elections and Macroeconomic Policy Cycles. NBER Working Paper 40 No. 1838.

Society and Economy 36 (2014) 
Schuknecht, L. (2000): Fiscal Policy Cycles and Public Expenditure in Developing Countries. Public Choice 102(1-2): 115-130.

Shi, M. - Svensson, J. (2002a): Conditional Political Budget Cycles. CEPR Discussion paper No. 3352.

Shi, M. - Svensson, J. (2002b): Political Budget Cycles in Developed and Developing Countries. Institute for International Economic Studies, Stockholm University. Accessed at: http://citeseerx.ist.psu.edu/viewdoc/download?doi=10.1.1.202.8595\&rep=rep1\&type=pdf

Shi, M. - Svensson, J. (2003): Political Budget Cycles: A Review of Recent Developments. Nordic Journal of Political Economy 29: 67-76.

8 Tufte, E. (1978): Political Control of the Economy. Princeton, NJ: Princeton University Press.

10

11

12

13

14

15

16

17

18

19

20

21

22

23

24

25

26

27

28

29

30

31

32

33

34

35

36

37

38

39

40

Society and Economy 36 (2014) 